\title{
Serotonin Regulates Type II Corticosteroid Receptor Binding in Hippocampal Cell Cultures
}

\author{
John B. Mitchell, Wayne Rowe, Patricia Boksa, and Michael J. Meaney \\ Douglas Hospital Research Center, Department of Psychiatry, McGill University, Montreal, Canada H4H 1R3
}

Previous work from our laboratory has shown that early postnatal handling of rat pups permanently increases hippocampal type II, but not type I, corticosteroid receptor binding. Handling also increases hippocampal 5-HT turnover, and the effect of handling on type II corticosteroid receptor binding is blocked by concurrent administration of the $5-\mathrm{HT}_{2}$ receptor antagonist ketanserin. In view of these findings, the present studies examined the effects of 5-HT on type I $\left(\left[{ }^{3} \mathrm{H}\right]\right.$ corticosterone) and type $\mathrm{II}\left(\left[{ }^{3} \mathrm{H}\right] \mathrm{RU} 28362\right)$ corticosteroid receptor binding in dispersed hippocampal cell cultures derived from animals killed at E19-20 in order to verify that 5-HT can act directly on hippocampal cells to alter corticosteroid receptor binding. Both type I and type II receptors were measurable in cultured hippocampal cells and the apparent affinity $\left(K_{\mathrm{c}}\right)$ for $\left[{ }^{3} \mathrm{H}\right]$ corticosterone $(0.4 \pm 0.1 \mathrm{nM})$ and [ $\left.{ }^{3} \mathrm{H}\right] R U 28362(0.8 \pm 0.1 \mathrm{nM})$ was similar to that from studies with intact animals. 5-HT increased type II, but not type I, corticosteroid receptor binding capacity in a dose-related manner, with the maximal effect $(+188 \%)$ observed at 10 nM 5-HT and no change in the affinity of the receptor for [ $\left.{ }^{3} \mathrm{H}\right] R U$ 28362. The effect of $10 \mathrm{nM} 5-\mathrm{HT}$ on [ $\left.{ }^{3} \mathrm{H}\right] \mathrm{RU} 28362$ binding required a minimum of $4 \mathrm{~d}$ exposure and persisted for at least $7 \mathrm{~d}$ following the removal of $5-\mathrm{HT}$. The effect of $10 \mathrm{nM}$ 5-HT on [ ${ }^{3} \mathrm{H}$ ]RU 28362 binding was completely blocked by the $5-\mathrm{HT}_{2}$ receptor antagonists ketanserin and mianserin. There were no effects of the 5- $\mathrm{HT}_{1 \mathrm{a}}$ antagonist, BMY 7378, or the $5-\mathrm{HT}_{3}$ antagonist, MDL 72222. The 5- $\mathrm{HT}_{2}$ agonists $\pm \mathrm{DOI}$, TFMPP, and quipazine significantly increased [ ${ }^{3} \mathrm{H}$ ]RU 28362 binding in cultured hippocampal cells. There was no effect of 8-OH-DPAT (5-HT, agonist) or 2-methyl-5-HT (5-HT, agonist). Finally, we demonstrated high affinity $\left(K_{d}=0.4 \pm 0.1\right.$ $\mathrm{nM})$, saturable [ ${ }^{125}$ ] 7 -amino-8-iodo-ketanserin binding, confirming the presence of $5-\mathrm{HT}_{2}$ receptors in hippocampal cell cultures. These data suggest that 5-HT can regulate type II, but not type I, corticosteroid receptor in cultured hippocampal cells most likely through an interaction with a $5-\mathrm{HT}_{2}$ receptor. Taken together with our recent in vivo studies, these data indicate that 5-HT mediates the developmental changes

Received Aug. 31, 1989; revised Dec. 14, 1989; accepted Dec. 15, 1989.

This work was supported by grants from the Mcdical Rescarch Council of Canada and les Fonds de Recherche en Sante du Quebec to M.J.M., who is a University Research Fellow of the Natural Sciences and Engineering Research Council of Canada (NSERC). J.B.M. is an NSERC postdoctoral fellow. We wish to thank Desta Packan and Robert Sapolsky of Stanford University for their assistance.

Correspondence should be addressed to Dr. Michael J. Meaney, Douglas Hospital Research Center, 6875 Boul. LaSalle, Montreal, Quebec, Canada H4H 1R3. Copyright (C) 1990 Society for Neuroscience $0270-6474 / 90 / 061745-08 \$ 02.00 / 0$ occurring in hippocampal type II corticosteroid receptors, including the influence of environmental events, and that the effect of 5-HT is exerted directly on hippocampal cells.

Corticosterone, the principle glucocorticoid (GC) in the rat, is concentrated by hippocampal cells (McEwen et al., 1969; Gerlach and McEwen, 1972; McEwen, 1982). The uptake of corticosterone by hippocampal cells is now thought to be associated with at least 2 distinct types of corticosteroid receptors (Veldhuis ct al., 1982; Coirini ct al., 1985; Rcul and de Kloet, 1985, 1986; McEwen et al., 1986). The type I receptor is restricted to the septohippocampal system, binds in vitro to both corticosterone and the mineralocorticoid aldosterone with high affinity, and binds the synthetic GC RU 28362 with very low affinity. The type II receptor, which is more diffusely distributed throughout the brain, binds corticosterone, dexamethasone, and RU 28362 with high affinity, and aldosterone with low affinity. Although both receptors bind corticosterone with high affinity, the $K_{\mathrm{d}}$ of the type I receptor for corticosterone $(\sim 0.5-1.0 \mathrm{nM})$ is lower than that of the type II receptor $(\sim 2.0-5.0 \mathrm{nM})$.

These receptors also exhibit strikingly different ontogenetic patterns. The type I receptor in hippocampus is apparent early in postnatal life at concentrations not different from those of adult animals (Rosenfield et al., 1988; Sarrieau et al., 1988). In contrast, type II receptor binding capacity in the hippocampus and throughout the forebrain is low during the first week of life and then increases, approximating adult values during the third week postnatally (Olpe and McEwen, 1976; Clayton et al. 1977; Meaney et al., 1985a; Rosenfield et al., 1988; Sarrieau et al., 1988). Moreover, development of the type II receptor in the hippocampus, unlike the type I receptor, is subject to environmental regulation (Meaney and Aitken, 1985; Meaney et al., 1985a, 1988; Sarrieau et al., 1988; Meaney et al., 1989).

To date little is known about the factors that regulate the development of corticosteroid receptors. Existing evidence strongly suggests that the development of the type II receptor occurs independent of the influences of circulating GCs (Meaney et al., 1985a, 1987; Sapolsky and Meaney, 1986). However, there are a number of putative neurotrophic factors that affect the maturation of hippocampal neurons during the postnatal period. 5-HT, which has been shown to have neurotrophic effects (Lauder, 1983), may be considered one possible regulator of type II receptor binding capacity during postnatal development. We have found that 5,7,-dihydroxytryptamine (5-7,DHT) lesions in day 2 pups decrease type II receptor binding in adult animals (Mitchell et al., 1990). Interestingly, neonatal handling of rat pups permanently increases type $1 /$ receptor binding in the hippocampus (Meaney et al., 1988) and this manipulation 
also increases 5-HT turnover in the hippocampus (Mitchell et al., 1990). There is considerable serotonergic activity in the rat forebrain during early development, as well as functional 5-HT receptors (see Lauder, 1983; Whitaker-Azmitia et al., 1987), and these findings are consistent with the apparent neurotrophic role of 5-HT in the developing CNS. Finally, we (Mitchell et al., 1990) have shown that the effect of handling on type II corticosteroid receptor binding is blocked by concurrent treatment with the $5-\mathrm{HT}_{2}$ antagonist ketanserin. However, it remains to be seen whether 5-HT can act directly on hippocampal cells to alter type II receptor binding.

In the experiments reported here we have examined the regulation of corticosteroid receptor binding capacity in cultures of dispersed hippocampal cells. The in vitro approach was taken in order to ensure that the serotonergic effects occurred directly on the hippocampal cells, a problem that has compromised the interpretation of the data from our in vivo experiments.

\section{Materials and Methods}

Cell cultures. The cell cultures were prepared according to a method derived from that of Banker and Cowan (1977). Medium ( $\mathrm{pH}$ at 7.3) consisted of Dulbecos Modified Eagle Medium (Gibco) containing 10\% fetal calf serum (Sigma, St. Louis, MO), $10 \mathrm{~nm}$ HEPES, $1 \mathrm{~mm}$ ascorbic acid, $5.2 \mathrm{mg} / 100 \mathrm{ml}$ gentamycin, $2 \mathrm{mg} / 100 \mathrm{ml}$ nystatin, $10,000 \mathrm{IU}$ penicillin $/ 100 \mathrm{ml}$, and $10 \mathrm{mg} / 100 \mathrm{ml}$ streptomycin, with glucose and glutamine increased to $0.2 \%$ and $0.8 \%$, respectively. Day $19-20$ fetuses were removed from pregnant female Long-Evans rats (Charles River Canada, St. Constant, Quebec) by laparotomy and the fetal hippocampi were dissected and placed in $1 \mathrm{ml}$ of medium. Cells were mechanically dissociated by trituration and seeded at a density of $1.5 \times 10^{6}$ cells $/ 10$ $\mathrm{ml}$ medium/dish on plastic Petri dishes $(100 \times 20 \mathrm{~mm})$, pretreated with poly-d-lysinc (Sigma). Threc days after plating, medium was replaced with medium that also contained $3 \mathrm{mg} / 100 \mathrm{ml}$ uridine and $1.5 \mathrm{mg} / 100$ $\mathrm{ml}$ flurodeoxyuridine in order to prevent proliferation of glial cells. Thereafter, cell cultures had $5 \mathrm{ml}$ of the medium replaced every $3-4 \mathrm{~d}$. Cell cultures were maintained at $37^{\circ} \mathrm{C}$ in a water-saturated atmosphere of $10 \% \mathrm{CO}$, in air. Except where stated, cell cultures were maintained for $17 \mathrm{~d}, 14 \mathrm{~d}$ from the time of the first feed, at which time the cells were harvested for binding assays.

Drugs. The antagonists used included (8-(2-(4-(2-methoxyphenyl)-1piperazinyl)ethyl)-8-azaspirol $(4,5)$-decane-7,9-dione dihydrochloride (BMY 7378), a specific 5-HT ${ }_{1 a}$ antagonist (Yocca et al., 1987; Chaput and de Montigny, 1988), 3-(2-(4-fluorobenzoyl)-2-piperdinyl)ethyl)$2,4(1 \mathrm{H}, 3 \mathrm{H})$-quinazolinedione (ketanserin), a $5-\mathrm{HT}_{2}$ antagonist (Leysen et al., 1982), mianserin, which is predominantly a $5-\mathrm{HT}_{2}$ antagonist, but with some action at the 5-HT Ic site (Hamon, 1983; Peroutka, 1988), and 3-tropanyl-3,5-dichlorobenzoate (MDL 72222), a selective 5-HT antagonist (Peroutka and Hamik, 1988). The agonists used included 8hydroxy-2-(di-n-propylamino)tetralin (8-OH-DPAT), a 5-HT $\mathrm{la}_{\mathrm{a}}$ agonist (Peroutka, 1985), the 5- $\mathrm{HT}_{1 \mathrm{~b}}$ and $5-\mathrm{HT}_{2}$ agonist $\mathrm{m}$-trifluoromethylphenylpiprazine (TFMPP; Glennon and Young, 1984), ( \pm )-1-(2,5-dimethoxy-4-iodophenyl)-2-aminopropane $( \pm \mathrm{DOI})$, a $5-\mathrm{HT}_{2}$ agonist (Shannon et al., 1984), 2-(1-piperazinyl)quinoline (quipazine), which binds to both the 5-HT, and 5-HT sites (Peroutka and Hamik, 1988), and 3-(2-aminoethyl)-2-methyl-1-1H-indol-5-ol (2-methyl-5-HT), a 5$\mathrm{HT}_{3}$ agonist (Richardson, et al., 1985; Fozard, 1987).

5-HT creatine sulfate was obtained from Sigma and BMY 7378 was provided by Bristol Myers (Evansville, IN). All other serotonergics were obtained from Research Biochemicals Inc. (Natick, MA). Unless stated otherwise, all drugs werc added to the cell cultures with $5 \mathrm{ml}$ replacement media every 3-4 d, starting on the third day after the cells were seeded.

Corticosteroid receptor assays. At the time of harvesting, the medium was removed and the cultures were rinsed with an isotonic buffer. The cells were scraped from the culture dish in $30 \mathrm{~mm}$ Tris, $1 \mathrm{~mm}$ ethylenediaminetetraacetic acid (EDTA), $10 \mathrm{~mm}$ molybdate, $10 \%$ (vol $/ \mathrm{vol}) \mathrm{glyc}-$ erol, and $1 \mathrm{~mm}$ dithiothreitol (TEDGM; pH 7.4). The sample was then sonicated and centrifuged at $0^{\circ} \mathrm{C}$ for $45 \mathrm{~min}$ at $105,000 \times \mathrm{g}$ in a Beckman L8-80 ultracentrifuge. Aliquots $(225 \mu \mathrm{l})$ of the resulting soluble fraction were incubated with $150 \mu \mathrm{l}$ aliquots of the radioligand in TEDGM at $4^{\circ} \mathrm{C}$ for $20-24 \mathrm{hr}$. For measurement of type II corticosteroid receptor binding capacity [ $\left.{ }^{3} \mathrm{H}\right] \mathrm{RU} 28362$ (spec. act. $77.5 \mathrm{Ci} / \mathrm{mmol}$; New England Nuclear, Boston, MA) was used as radioligand in an incubation range of $0.1-15.0 \mathrm{nM}$ for saturation experiments and at a saturating, $10 \mathrm{nM}$ concentration in single-point assays. RU 28362 has been shown to be a highly specific ligand for the type II receptor site, with little or no affinity for type I sites (Philbert and Moguilewsky, 1983; Coirini et al., 1985; Reul and de Kloet, 1985). Type I corticosteroid receptor binding was measured according to the method of Reul and de Kloet (1985) using $\left[{ }^{3} \mathrm{H}\right]$ corticosterone (spec. act. $101.6 \mathrm{Ci} / \mathrm{mmol}$; New England $\mathrm{Nu}$ clear) in an incubation range of $0.1-15.0 \mathrm{~nm}$ for saturation experiments and at a saturating, $10 \mathrm{~nm}$ concentration in single-point assays. For determination of type $\mathrm{I}$ sites $\left[{ }^{3} \mathrm{H}\right]$ corticosterone binding was measured in the presence of $100 \mathrm{nM}$ unlabeled RU 28362 in order to block radioligand binding to type II sites. In all cases, nonspecific binding was determined with parallel incubations that contained a 500 -fold excess of unlabeled corticosterone.

The bound and unbound ligand in $100 \mu \mathrm{l}$ aliquots of incubate were separated with Sephadex LH-20 (Pharmacia Fine Chemicals, Dorval, Quebec, Canada) columns $(7 \times 1 \mathrm{~cm})$ equilibrated with TEDGM. The columns were eluted into minivials which were then filled with $5 \mathrm{ml}$ Liquiscint (National Diagnostics, Somerville, NJ) and counted in an LKB scintillation counter at $40 \%$ efficiency. A theoretical maximal number of binding sites $\left(B_{\max }\right)$ and dissociation constant $\left(K_{\mathrm{u}}\right)$ were derived using Scatchard analysis (Scatchard, 1949). Protein content was determined by the method of Bradford (1976), and results were expressed as $\mathrm{fmol} / \mathrm{mg}$ protein. Individual experiments used cultures $(n=5-6)$ from at least 2 separate preparations.

$5-\mathrm{HT}_{2}$ receptor assays. For the measurement of $5-\mathrm{HT}_{2}$ receptor binding, cultures were scraped into $50 \mathrm{nM}$ Tris $\mathrm{HCl}$, centrifuged at $4900 \times$ $g$ for $15 \mathrm{~min}$ at $4^{\circ} \mathrm{C}$, and the pelleted membranes were then washed twice by resuspension in $50 \mathrm{~nm}$ Tris $\mathrm{HCl}$ followed by centrifugation. Aliquots $(300 \mu \mathrm{l})$ of membrane were incubated with $200 \mu \mathrm{l}$ aliquots of [125I] 7-amino-8-iodo-ketanserin ([125I]AMIK; spec. act. $1011 \mathrm{Ci} / \mathrm{mmol}$; Amersham) in a concentration range of $0.05-1.5 \mathrm{nM}$. Nonspecific binding was determined with parallel incubations containing a 1000 -fold excess of unlabeled ketanserin. Bound and free ligand were separated by filtration with Whatman GF/B glass fiber filters. Experimental data were analyzed using Scatchard and Hill plots. Results were expressed as $\mathrm{fmol} / \mathrm{mg}$ protein.

Immunohistochemistry. The presence of glial fibrillary acidic protein (GFAP) was demonstrated using an immunohistochemical kit (Sigma) in which an antigen-specific primary antibody, rabbit anti-GFAP, was applied to hippocampal cells cultured on poly-d-lysine coated glass coverslips. The coverslips were then incubated with a biotinylated secondary antibody, goat anti-rabbit IgG. Antibody deposition was visualized by the addition of $3 \%$ hydrogen peroxide and 3-amino-9-ethylcarbazole. Coverslips were counterstained with Mayer's hematoxylin and mounted on microscope slides with glycerol-gelatin mounting media. The coverslips were examined under a light microscope by 2 independent observers and the number of GFAP-positive and GFAPnegative cells counted ( $\sim 500$ cells from both 5 -HT treated and control cultures were counted).

Statistical analysis. Unless otherwise stated, the data were analyzed with one-way analyses of variance followed by Fisher's post hoc tests where appropriate.

\section{Results}

Characterization of cultures. The cultures used in these studies were established under conditions previously shown to promote neuronal survival and increase the percentage of neurons to non-neuronal cells (see Banker and Cowan, 1977). Immunohistochemical examination showed that the cultures contained a low percentage of GFAP-positive cells regardless of whether they had been exposed to 5-HT or to control conditions for $14 \mathrm{~d}$ (23\% and $19 \%$ of the cells counted, respectively). There was a high percentage of GFAP-negative cells that had at least one branching process more than one cell diameter in length $(74 \%$ and $77 \%$, for control and 5-HT treated cultures, respectively). These cells appeared to possess the characteristic morphology of hippocampal pyramidal neurons, and the processes of dispersed cells typically formed a dense plexus. Thus, the cultures 

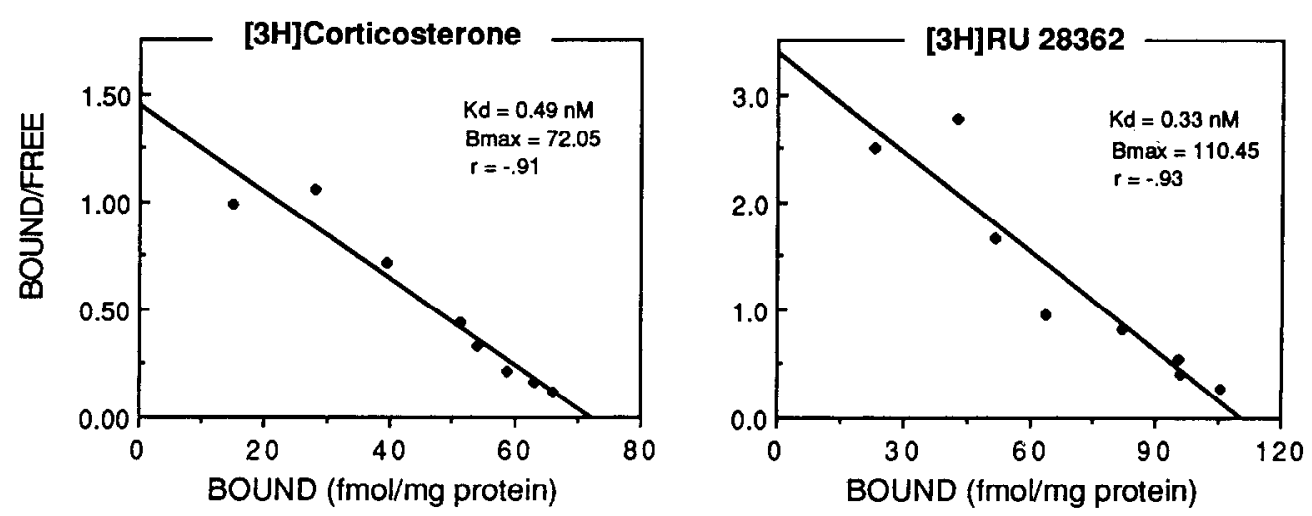

Figure 1. Representative Scatchard plots of type I (left panel) and type II (right panel) corticosteroid receptor binding in dispersed hippocampal cells after $17 \mathrm{~d}$ in culture.

used in these studies were predominantly neuronal. These results are similar to those reported previously for cultures that are seeded at a high density and treated with inhibitors of glial proliferation (Banker and Cowan, 1977; Barochovsky and Bradford, 1987).

Corticosteroid receptors in hippocampal cell cultures. We first examined type I and type II corticosteroid receptor binding in cultured hippocampal cells (see Fig. 1). For type II receptor binding assays ( $\left[{ }^{3} \mathrm{H}\right] \mathrm{RU} 28362$ binding) we found a $B_{\text {max }}$ of 107.5 $\pm 14 \mathrm{fmol} / \mathrm{mg}$ protein and a $K_{\mathrm{d}}$ of $0.8 \pm 0.1 \mathrm{nM}$. For type I reeceptor binding $\left(\left[{ }^{3} \mathrm{H}\right]\right.$ corticosterone in the presence of cold RU 28362) we found a $B_{\max }$ of $82.5 \pm 20 \mathrm{fmol} / \mathrm{mg}$ protein and a $K_{\mathrm{d}}$ of $0.4 \pm 0.1 \mathrm{~nm}$. These $K_{\mathrm{d}}$ values are well within the range of those previously reported from studies with whole hippocampus (e.g., Reul and de Kloet, 1985; Sheppard and Funder, 1987). The similarity in type I and type II receptor binding capacity in rat hippocampus has been previously reported (Reul and de Kloet, 1985; Sarrieau et al., 1988). Thus, the type I and type II receptor binding parameters were similar to receptor assays performed with freshly dissected hippocampal tissue from rats adrenalcctomized 12-24 hr prior to killing.

The medium used in these studies was supplemented with fetal calf serum containing low concentrations of adrenal steroids (i.e., $\sim 100$ pM corticostereone, 800 pM cortisol, and 3 pM desoxycorticosterone according to the values provided by the supplier). Thus, we examined the potential effects of these trace levels of steroids in the serum-containing medium on corticosteroid receptor binding since steroid within the media could mask receptor sites, particularly the higher-affinity type I receptor. This was done in 2 ways. First, the steroids were "stripped" by passing the medium through $10 \times 1 \mathrm{~cm}$ Sephadex LH-20 columns. Cultures were then maintained in either stripped or unstripped medium. Second, prior to assay, the soluble fraction prepared from cell cultures maintained with untreated medium was passed through $10 \times 1 \mathrm{~cm} \mathrm{LH}-20$ columns to remove any residual steroid (i.e., stripped soluble fraction). There was no significant effect of the removal of steroids by $\mathrm{LH}-20$ on either the affinity $\left(K_{\mathrm{d}}\right)$ or the binding capacity $\left(B_{\max }\right)$ for either type I or type II corticosteroid receptors (see Table 1), indicating that the low levels of the adrenal steroids in the serum did not interfere with the corticosteroid receptor binding assays.

Effect of 5-HT on corticosteroid receptor binding. Cell cultures were exposed to various concentrations of 5 -HT $(0,1,10$, or $100 \mathrm{~nm}$ ) in the medium beginning on the third day after seeding and type I and type II corticosteroid receptor binding was mea- sured using single-point assays $14 \mathrm{~d}$ later. Exposure to 5-HT resulted in a dose-related increase in type $\mathrm{II}$, corticosteroid receptor binding capacity ( $p<0.01$; see Fig. 2$)$. The increase in $\left[{ }^{3} \mathrm{H}\right] \mathrm{RU} 28362$ binding was significant with the 10 and $100 \mathrm{nM}$ 5 -HT concentrations $(p<0.01)$. The estimated $\mathrm{ED}_{50}$ for 5-IIT was $4.3 \mathrm{~nm}$ and, as can be seen in Figure 2, the maximal effect was achieved at $10 \mathrm{nM} 5$-HT. There were no significant changes in type I corticosteroid receptor binding capacity (see Fig. 2). We then examined the effects of the same range of 5-HT concentrations on [ $\left.{ }^{3} \mathrm{H}\right] \mathrm{RU} 28362$ binding using saturation experiments. These data replicate the earlier study and indicate that the effect of 5-HT on [ $\left.{ }^{3} \mathrm{H}\right] \mathrm{RU} 28362$ binding was expressed solely in terms of the number of receptor sites for [ $\left.{ }^{3} \mathrm{H}\right] \mathrm{RU} 28362$, with no significant change in the affinity of the receptor for $\left[{ }^{3} \mathrm{H}\right] \mathrm{RU} 28362$ (see Fig. 3). These results indicate that 5-HT selectively increases type II, but not type I, corticosteroid receptor binding capacity in cultured hippocampal cells.

Time course. We then examined the time course of the effect of 5-HT on type II corticosteroid receptor binding (see Fig. 4). Hippocampal cell cultures were exposed to $10 \mathrm{~nm} 5$-HT or the media alone for the last $1,2,4,7$, or $14 \mathrm{~d}$ in culturc. Type II reeceptor binding was significantly $(p<0.05)$ elevated in cell cultures following 4,7 , or $14 \mathrm{~d}$ of exposure to $10 \mathrm{~nm} 5-\mathrm{HT}$. Exposure of the cultures to $10 \mathrm{~nm} 5-\mathrm{HT}$ for 1 or $2 \mathrm{~d}$ had no effect on $\left[{ }^{3} \mathrm{H}\right] \mathrm{RU} 28362$ binding. Thus, the increase in type II corticosteroid receptor binding induced by $5-\mathrm{HT}$ required $4 \mathrm{~d}$ of exposure to 5-HT and there was little increase in binding after that time.

We then examined the persistence of the effect of 5-HT. Cell cultures were exposed to 5-HT during the first week in culture and control conditions during the second week to assess the

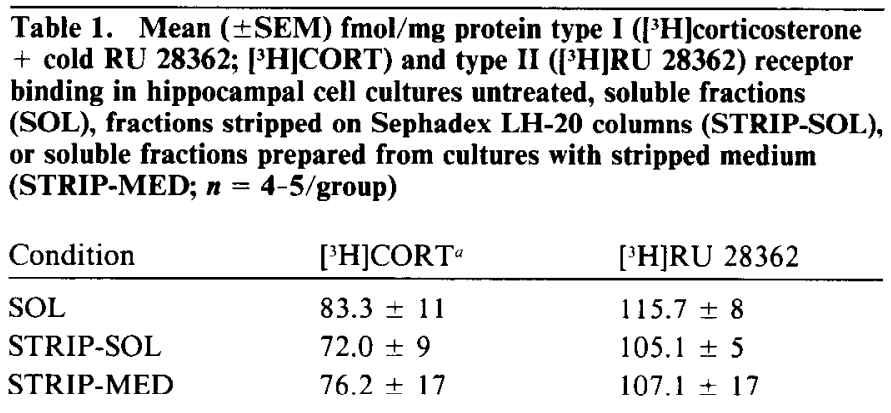

"In the presence of an excess of cold RU 28362 

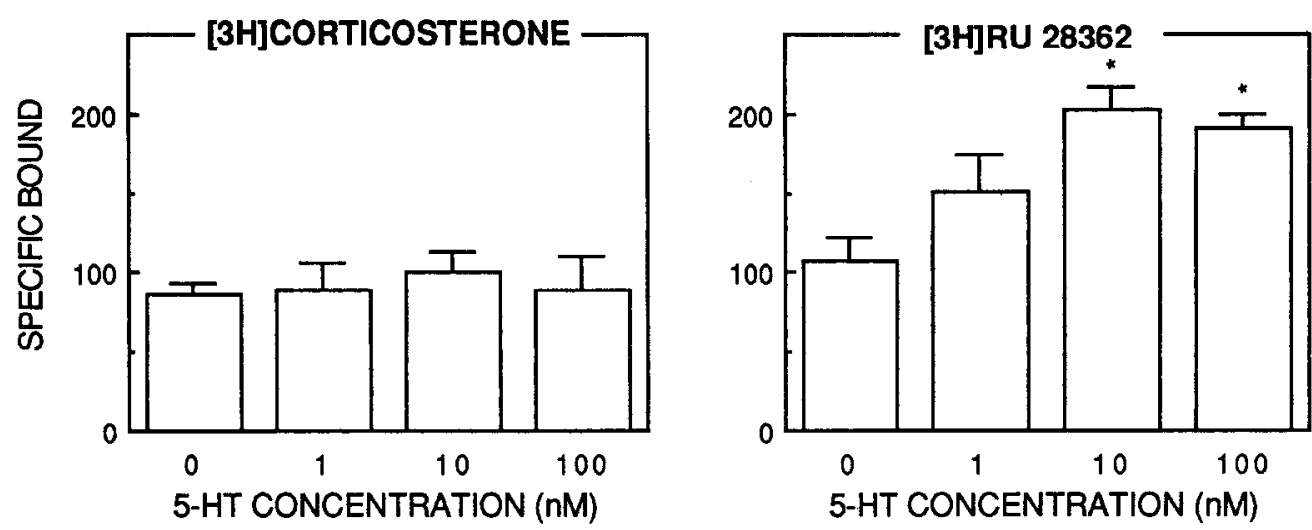

Figure 2. Mean ( \pm SEM) specific binding (fmol/mg protein) of $\left[{ }^{3} \mathrm{H}\right]$ corticosterone (left panel) and $\left[{ }^{3} \mathrm{H}\right] \mathrm{RU} 28362$ (right panel) in cultures exposed to $0,1,10$, or $100 \mathrm{nM} 5$-HT for $14 \mathrm{~d}$ starting on the third day after seeding. ${ }^{*}$ Significantly different from 0 nM 5 -HT controls $(n=6)$.

persistence of the elevation in corticosteroid type II binding capacity, or to control conditions during the first week and 5-HT during the second week, replicating the $7 \mathrm{~d}$ condition of the previous experiment. Controls were exposed to control conditions during the entire 2 weeks (see Fig. 5). Regardless of whether the cells were exposed to 5-HT only during the first or last week, [ $\left.{ }^{3} \mathrm{H}\right] \mathrm{RU} 28362$ binding was significantly increased as compared to cells exposed to control conditions during the entire 2 week period $(p<0.01)$. Moreover, cell cultures exposed to $5-\mathrm{HT}$ during the first week only or the last week only did not differ significantly from each other. Thus, the change in type II corticosteroid receptor capacity persisted for at least $7 \mathrm{~d}$ following the removal of 5-HT. These data also demonstrate that the presence of 5-HT at the time that the cells were collected and assayed was not necessary for the observed increase in type II receptor binding.

5-HT agonist and antagonist studies. The investigation of 5-HT receptors has revealed that $5-\mathrm{HT}$ interacts with a variety of receptor subtypes (see Peroutka, 1988, for a recent review). In order to determine which of the known 5-HT receptor subtypes might mediate the effect of 5-HT on type II corticosteroid receptor binding capacity, we examined the ability of various antagonists (in $100 \mathrm{~nm}$ concentrations) to block the effects of 10

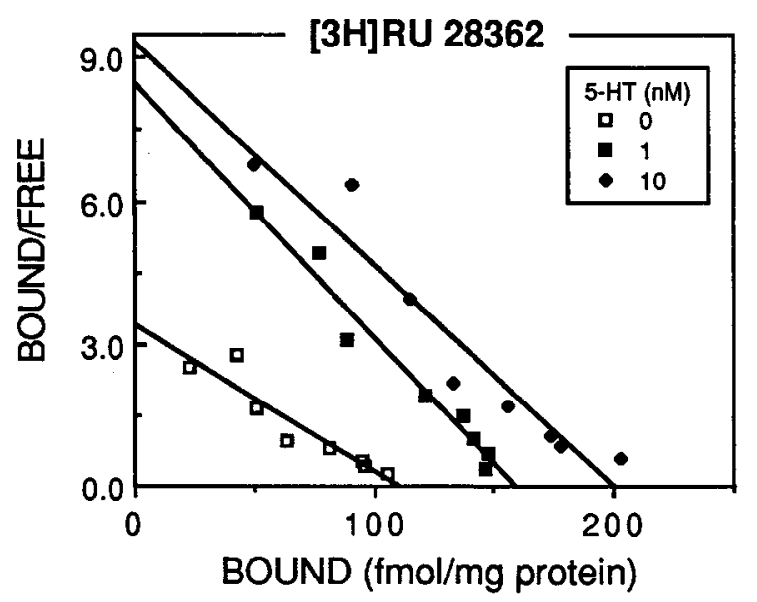

Figure 3. Scatchard analysis of specific $\left[{ }^{3} \mathrm{H}\right] \mathrm{RU} 28362$ binding in dispersed cell cultures exposed to 0,1 , or $10 \mathrm{nM} 5-\mathrm{HT}$ for $14 \mathrm{~d}$ starting on the third day after seeding $(n=5-6)$.
nM 5-HT on type II receptor binding, as well as the ability of various agonists to mimic the effects of $10 \mathrm{~nm} 5-\mathrm{HT}$. Cultures were exposed to drug treatment for $14 \mathrm{~d}$ and then assayed for type II receptor binding.

$\left[{ }^{3} \mathrm{H}\right] \mathrm{RU} 28362$ binding capacity was significantly $(p<0.05)$ increased in cell cultures treated with $10 \mathrm{nM} 5-\mathrm{HT}$, and the influence of 5-HT was unaffected by the presence of either BMY 7378 or MDL 72222 (administered in combination with $10 \mathrm{nM}$ 5-HT; see Fig. 6). In contrast, $\left[{ }^{3} \mathrm{H}\right] \mathrm{RU} 28362$ binding in cell cultures treated with $10 \mathrm{nM} 5-\mathrm{HT}$ in the presence of ketanserin or mianserin did not differ significantly from controls and showed significantly less [ $\left.{ }^{3} \mathrm{H}\right] \mathrm{RU} 28362$ binding than cultures exposed to $10 \mathrm{~nm} 5$-HT alone $(p<0.05)$. Thus, both ketanserin and mianserin were able to block the 5-HT-induced increase in $\left[{ }^{3} \mathrm{H}\right] \mathrm{RU} 28362$ binding.

Cultures treated with either \pm DOI, TFMPP, or quipazine had significantly increased [ $\left.{ }^{3} \mathrm{H}\right] \mathrm{RU} 28362$ binding above control levels ( $p<0.05$, see Fig. 7). However, the \pm DOI- and TFMPPtreated cell cultures displayed lower levels of $\left[{ }^{3} \mathrm{H}\right] \mathrm{RU} 28362$ binding than did cultures exposed to $10 \mathrm{nM} 5-\mathrm{HT}(p<0.05)$. Quipazine-treated cultures, however, did not differ significantly from $10 \mathrm{~nm} 5$-HT-treated cultures. Cells cultured in the presence of a $100 \mathrm{~nm}$ concentration of \pm DOI again showed increased $\left[{ }^{3} \mathrm{H}\right] \mathrm{RU} 28362$ binding over controls, but less than that for 10 nM 5-HT (data not shown). Neither 8-OH-DPAT nor 2-methyl5 -HT significantly increased [ $\left.{ }^{3} \mathrm{H}\right] \mathrm{RU} 28362$ binding above control conditions, and all of these treatments resulted in significantly lower [ ${ }^{3} \mathrm{H}$ ]RU 28362 binding than $10 \mathrm{nM} 5$-HT $(p<$ $0.05)$.

5- $\mathrm{HT}_{2}$ receptor binding in hippocampal cell cultures. The data presented above suggest that the effect of $10 \mathrm{~nm} 5-\mathrm{HT}$ on type II corticosteroid receptor binding is mediated, in part at least, by the $5-\mathrm{HT}_{2}$ receptor. Therefore, it was of considerable interest to confirm the existence of $5-\mathrm{HT}_{2}$ receptors in our hippocampal cell cultures. For 5- $\mathrm{HT}_{2}$ binding, Scatchard analyses of saturation experiments with [ $\left.{ }^{125} \mathrm{I}\right] \mathrm{AMIK}$ as radioligand revealed a $B_{\max }$ $=24.5 \pm 4 \mathrm{fmol} / \mathrm{mg}$ protein and $K_{\mathrm{d}}=0.4 \pm 0.1 \mathrm{nM}(n=6$ separate experiments, see Fig. 8).

\section{Discussion}

These data demonstrate that 5-HT can increase type II, but not type I, corticosteroid receptor binding capacity in primary cultures of dispersed hippocampal cells. This increase required a minimum of $4 \mathrm{~d}$ to occur, suggesting that the 5 -HT-induced 


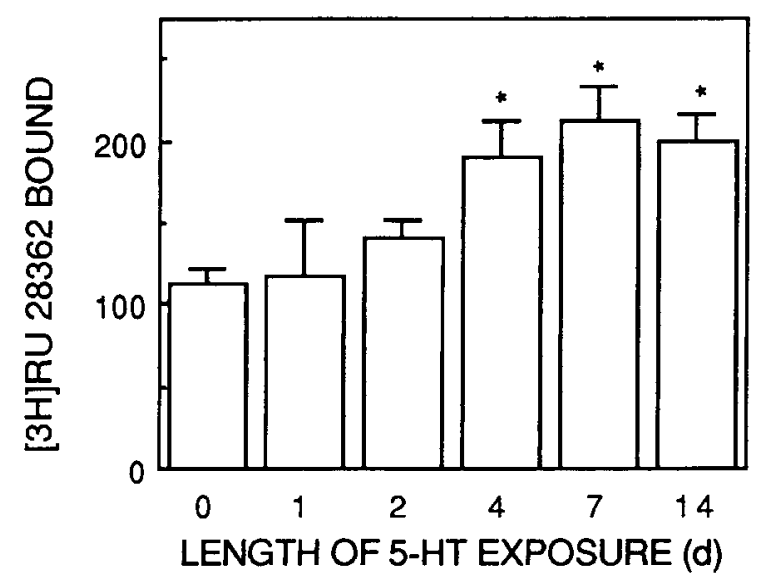

Figure 4. Mean ( \pm SEM) specific binding of $\left[{ }^{3} \mathrm{H}\right] \mathrm{RU} 28362$ in cultures exposed to control conditions, or to $10 \mathrm{~nm} 5$-HT for the final 1, 2, 4, 7 , or $14 \mathrm{~d}$. All cultures were maintained for $17 \mathrm{~d}$. *Significantly different from controls $(n=6)$.

increase in [ $\left.{ }^{3} \mathrm{H}\right] \mathrm{RU} 28362$ binding may involve the synthesis of new receptors. In light of these data, it is interesting that Barzilai et al. (1989) have recently reported that prolonged exposure to 5-HT can regulate the expression of specific proteins, an effect that is blocked by protein or RNA synthesis inhibitors. Moreover, the effect on type II receptor binding persisted for at least 1 week following the removal of 5-HT, suggesting that there was a lasting change in the expression of the type II corticosteroid receptors. There was no effect of 5-HT on the affinity of either type I or type II receptors for $\left[{ }^{3} \mathrm{H}\right]$ corticosterone or $\left[{ }^{3} \mathrm{H}\right] \mathrm{RU}$ 28362 , respectively.

The effect of 10 nм 5-HT on $\left[{ }^{3} \mathrm{H}\right] \mathrm{RU} 28362$ binding was completely blocked by the $5-\mathrm{HT}_{2}$ antagonists ketanserin and mianserin. Similarly, the effect of 5-HT was mimicked, at least in part, by the agonists DOI, TFMPP, and quipazine. The 5-HT ${ }_{2 \mathrm{H}}$ site, proposed by Titeler and co-workers (Battaglia et al., 1983a, b, 1984; Titeler et al., 1984; Lyon et al., 1987), binds with high affinity to DOI, TFMPP, and quipazine (Titeler et al., 1987; but see Cory et al., 1987), and Titeler et al. (1987) rcport a $K_{\mathrm{d}}$ of about $5 \mathrm{~nm}$ for 5-HT itself. This $K_{\mathrm{d}}$ is certainly a good approximation of the $\mathrm{ED}_{50}$ of $4.3 \mathrm{nM}$ for the effect of 5-HT on type II corticosteroid receptor binding. The [25I]AMIK binding data indicate the presence of 5- $\mathrm{HT}_{2}$ receptors in cultured hippocampal cells. Quipazine was the only agonist to fully mimic the effect of 5-HT on type II corticosteroid receptor binding, and although quipazine appears to be active at the 5- $\mathrm{HT}_{1}$ and 5-HT 3 sites (Blackshear et al., 1981; Peroutka and Hamik, 1988), the potent 5- $\mathrm{HT}_{1 \mathrm{a}}$ and 5- $\mathrm{HT}_{3}$ agonists 8-OH-DPAT and 2-methyl-5-HT had no effect on corticosteroid receptor binding (see Fig. 7). It is possible that the effect of 5-HT on type II corticosteroid binding was mediated via the $5-\mathrm{HT}_{1 \mathrm{c}}$ receptor. Mianserin has high affinity for both the $5-\mathrm{HT}_{1 \mathrm{c}}$ and $5-\mathrm{HT}_{2}$ receptors, and the concentration of ketanserin that was effective could act at 5-HT $\mathrm{H}_{\mathrm{lc}}$ sites (Hoyer et al., 1985). The 5-HT agonists that were found to bc cffcctivc may also activate $5-\mathrm{HT}_{1 \mathrm{c}}$ receptors (Kennett and Curzon, 1988; Sanders-Bush et al., 1988; Lucki et al., 1989). The effect of 5-HT on type II corticosteroid binding, therefore, appears to involve activity at the $5-\mathrm{HT}_{2}$ site, but the $5-\mathrm{HT}_{\mathrm{Ic}}$ receptor may also be involved.

It is not clear from these studies whether the effect of 5-HT on type II receptor binding occurs in neurons, glia, or both.

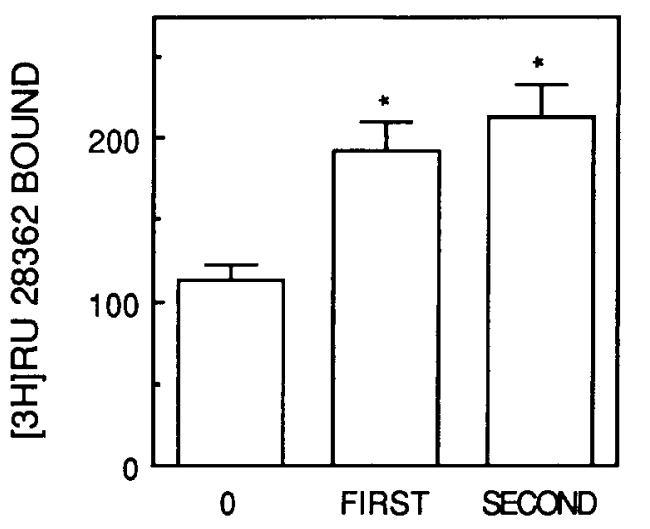

\section{TIMING OF 5-HT EXPOSURE (wk)}

Figure 5. Mean ( \pm SEM) specific binding of [ $\left.{ }^{3} \mathrm{H}\right] \mathrm{RU} 28362$ in controls and cultures exposed to $10 \mathrm{nM} 5$-HT during the first or last $7 \mathrm{~d}$. *Significantly different from controls $(n=6)$.

Type II corticosteroid receptors are known to exist in both neurons and glia (see McEwen and Wallach, 1973; McEwen et al., 1986) and both cell types appear to contain 5-HT receptors (Hertz et al., 1979; Fillion et al., 1983). Considering the high percentage of neurons in our cultures and the magnitude of the effect on type II receptor binding, it would be surprising if the effect were not, to some extent, occurring in neurons. We are currently examining this issue.

The hippocampus receives serotonergic innervation primarily from the median raphe nucleus (Azmitia and Segal, 1978). There is both electrophysiological (Azmitia et al., 1984) and anatomical (Gerlach and McEwen, 1972) evidence that at least some of the serotonergic inputs to the hippocampus interact with cells that also concentrate corticosterone, suggesting that 5 -HT could act directly on hippocampal cells to modulate the concentration of type II corticosteroid receptor binding sites in vivo. We have

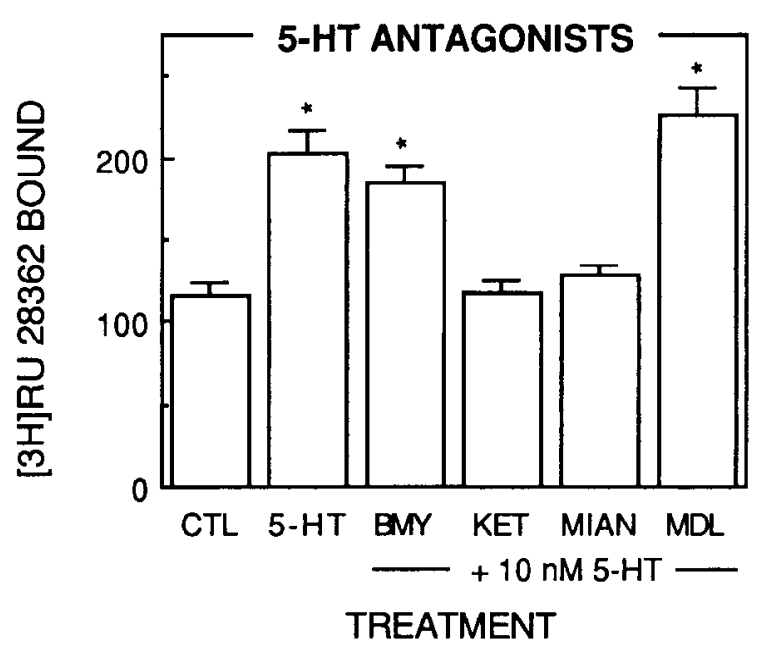

Figure 6. Mean ( \pm SEM) specific binding of $\left[{ }^{3} \mathrm{H}\right] \mathrm{RU} 28362$ in controls (CTL) and cultures exposed to $10 \mathrm{nM} 5$-HT, or $10 \mathrm{nM} 5$-HT with 100 nм of BMY $7378(B M Y)$, ketanserin (KET), mianserin $(M I A N)$, or MDL $72222(M D L)$. Cultures were exposed to treatments for $14 \mathrm{~d}$ starting on the third day after seeding. *Significantly different from controls $(n$ $=6$ ). 


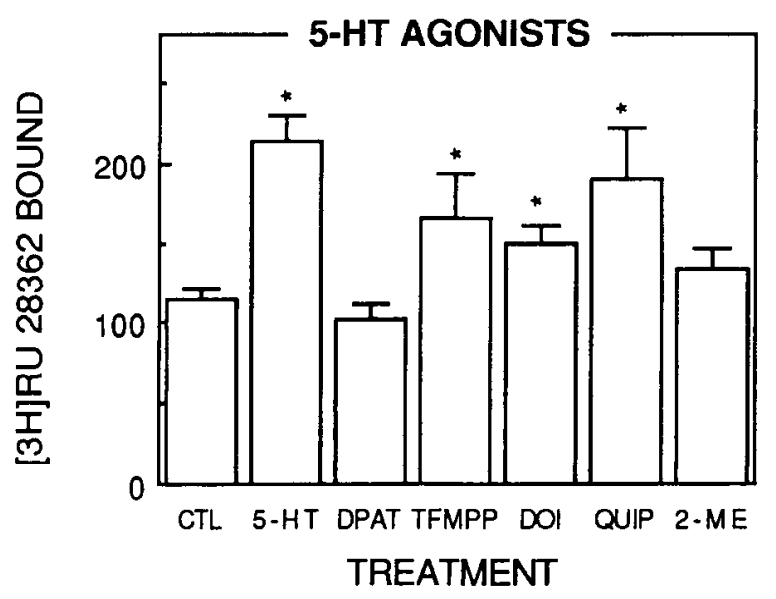

Figure 7. Mean ( \pm 1 SEM) specific binding of [ $\left.{ }^{3} \mathrm{H}\right] \mathrm{RU} 28362$ in controls $(C T L)$ and cultures exposed to $10 \mathrm{nM}$ concentrations of either 5 HT, 8-OH-DPAT (DPAT), TFMPP, $\pm D O I$, quipazine (QUIP), or 2methyl-5-HT (2-ME). Cultures were exposed to treatments for $14 \mathrm{~d}$ starting on the third day after seeding. *Significantly different from controls $(n=6)$.

recently provided evidence from in vivo studics for the rolc of 5-HT both in the normal development of hippocampal type II corticosteroid receptors and in mediating the effects of early environmental stimulation on hippocampal type II corticosteroid receptor binding (Mitchell et al. 1990). Thus, adult animals treated on day 2 of life with the 5-HT neurotoxin 5,7-DHT showed decreased type II receptor binding in the hippocampus. Neonatal thyroid hormone treatment increases hippocampal type II receptor binding capacity (Meaney et al. 1987) and hippocampal 5-HT turnover (Mitchell et al., 1990). Likewise, postnatal handling, a manipulation that permanently increases type II, but not type I, corticosteroid receptor binding in the hippocampus (Meaney et al., 1985b, 1988, 1989; Meaney and Aitkin, 1985; Sarrieau et al., 1988) also increases hippocampal 5-H T turnover (Mitchell et al., 1990). Finally, we have found that concurrent treatment with ketanserin blocks the effects of handling on hippocampal type II corticosteroid receptor binding. Taken together, these data suggest that alterations in 5-HT mediate the influence of environmental events, such as handling, on the development of type II receptors in the hippocampus.

Such effects appear to have considerable physiological consequence for the animal. Adult animals handled daily for the first weeks of life show greatly attenuated corticosterone secretion both during and following the termination of stress (e.g., Levine, 1957, 1962; Levine et al., 1967; Ader and Grota, 1969; Meaney et al., 1989). Neonatal handling increases type II receptor binding in the hippocampus, a brain region known to be involved in the negative-feedback control over hypothalamicpituitary-adrenal activity (Meaney et al., 1985b, 1987, 1989; Meaney and Aitken, 1985; Sarrieau et al., 1988). The increase in type II receptors is associated with increased negative-feedback sensitivity to both corticosterone and dexamethasone (Mcancy ct al., 1989). Reducing hippocampal type II receptor levels to those of nonhandled animals (through chronic corticosterone treatment) eliminates the difference in stress-induced corticosterone secretion (Meaney et al., 1989). Thus, environmental stimulation early in life increases type II corticosteroid receptor binding in the hippocampus and, in doing so, permanently alters the HPA response to stress.

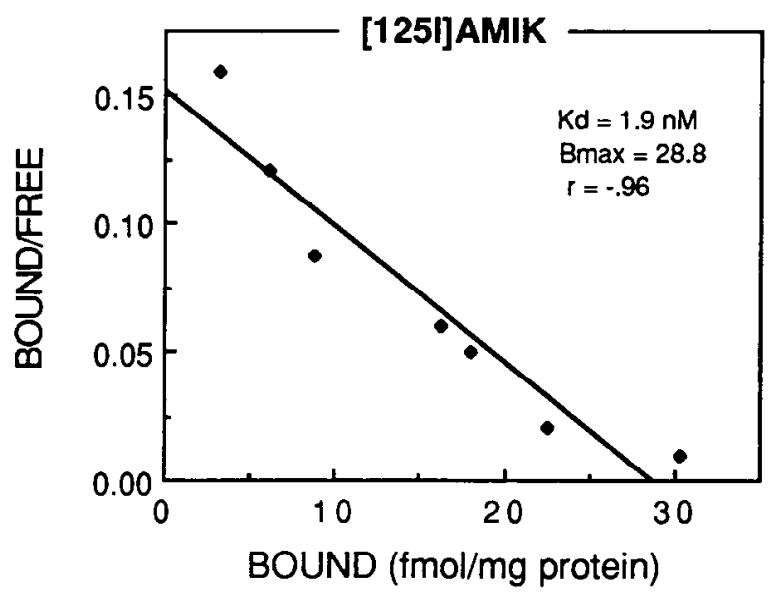

Figure 8. Representative Scatchard plot of [ ${ }^{125}$ I]AMIK receptor binding in dispersed hippocampal cells after $17 \mathrm{~d}$ in culture.

The effect of 5-HT on type II receptor binding in early development appears to differ considerably from that in the adult. There is one report that chemical lesions of the dorsal raphe nucleus decreased $\left[{ }^{3} \mathrm{H}\right]$ corticosterone binding (a measure of both type I and II receptors) in the hippocampus of adult rats ( $\Lambda \mathrm{n}$ gelucci et al., 1982). However, this finding is difficult to interpret since the lesion also affected the affinity $\left(K_{\mathrm{d}}\right)$ of the receptor for $\left[{ }^{3} \mathrm{H}\right]$ corticosterone. Furthermore, chlorimipramine, a 5-HT reuptake inhibitor, quipazine, and methysergide, a 5-HT antagonist, all decreased $\left[{ }^{3} \mathrm{H}\right]$ corticosterone binding. Other attempts to influence hippocampal type II receptor binding capacity (measured using [ $\left.{ }^{3} \mathrm{H}\right] \mathrm{RU} 28362$ ) in adult animals by manipulation of serotonergic systems, including 5,7-DHT lesions, have been unsuccessful (Mitchell et al., 1990; M. Lowy, personal communication). In the adult, then, 5-HT appears to have little or no effect on type II receptor binding. Thus, the evidence to date suggests that 5-HT exerts a potent regulatory effect on hippocampal type II corticosteroid receptor binding capacity that is specific to early periods of development.

Regulation of type II receptor sites during development differs considerably from that in the adult period. Postnatally, type II, but not type I, corticosteroid receptor densities are low in the hippocampus and increase dramatically beginning by the second week of life (Meaney et al., 1985b; Rosenfield et al., 1988; Sarrieau et al., 1988). In the adult rat, hippocampal type II corticosteroid receptor binding capacity is regulated by circulating corticosterone levels. Thus, increased corticosterone levels are associatcd with a decrease in typc II receptor binding (Tornello et al., 1982; Sapolsky et al., 1984), and steroid removal by adrenalectomy increases type II corticosteroid receptor binding (McEwen et al., 1974; Olpe and McEwen, 1976; Turner, 1986). During the first 2-3 weeks of life, however, neither chronic corticosterone administration nor adrenalectomy influences hippocampal type II corticosteroid receptor binding capacity (Meaney et al., 1985b, 1987; Sapolsky and Meaney, 1986). Rather, type II corticosteroid reeceptor binding capacity is independent of circulating corticosterone titers in the neonate, and the homologous control of receptor concentrations gradually emerges with age. Thus, the regulation of type II receptor binding capacity in the neonate differs from that in the adult. At some point in development there must occur a shift in the sensitivity of hippocampal cells expressing the type II receptor gene such that the factors regulating the ontogeny of the receptor differ, at 
least in part, from those involved in the more dynamic regulation of receptor binding during adult life. The results of the studies reported here suggest that 5-HT is one factor responsible for the early control of type II corticosteroid receptor concentrations in the hippocampus. Regulatory factors early in development, such as those of early handling, can persist throughout the life of the animal. Postnatal handling results in increased type II receptor binding in animals tested as late as 24 months of age (Meaney et al., 1988). In this context, it is interesting that the effects of $10 \mathrm{~nm}$ 5-HT on type II receptor binding persisted even for at least $7 \mathrm{~d}$ following the removal of 5-HT from the media (see Fig. 5). While this period is comparatively brief, the data presented here, together with our in vivo studies on the role of 5-HT in mediating the effects of early environmental stimulation, suggest that these cell culture studies might provide a model for the study of the neural regulation of type II receptor gene expression in the developing brain.

\section{References}

Ader R, Grota LJ (1969) Effects of early experience on adrenocortical reactivity. Physiol Behav 4:303-305.

Angelucci L, Patacchioli FR, Bohus B, de Kloet R (1982) Serotonergic innervation and glucocorticoid binding in the hippocampus: relevance to depression. In: Typical and atypical antidepressants: molecular mechanisms (Costa E, Racagni G, eds), pp 365-370. New York: Raven.

Azmitia E, Segal M (1978) The efferent connections of the dorsal and median raphe nuclei in the rat brain. J Comp Neurol 179:641-668.

Azmitia EC, McNaughton N, Tsaltas L, Fillenz M, Gray JA (1984) Interactions between hippocampal serotonin and the pituitary-adrenal axis in the septal driving of hippocampal theta-rhythm. Neuroendocrinology 39:471-475.

Banker GA, Cowan WM (1977) Rat hippocampal neurons in dispersed cell culture. Brain Res 126:397-425.

Barochovsky O, Bradford HF (1987) Development of transmitterreleasing capacity in neuron-enriched tissue cultures. J Neurochem 48:787-797.

Barzilai A, Kennedy TE, Sweatt JD, Kandel ER (1989) 5-HT modulates protein synthesis and the expression of specific proteins during long-term facilitation in aplysia sensory neurons. Neuron 2:15771586.

Battaglia G, Shannon M, Borgundvaag B, Titeler M (1983a) pH-dependent modulation of agonist interactions with ${ }^{3} \mathrm{H}$-ketanserin-labelled S2 receptors. Life Sci 33:2011-2016.

Battaglia G, Shannon M, Titeler M (1983b) Modulation of brain S2 serotonin receptors by lithium, and sodium and potassium chloride. Life Sci 32:2597-2602.

Battaglia G, Shannon M, Borgundvaag B, Titeler M (1984) Guanyl nucleotide and divalent cation regulation of cortical $S 2$ serotonin receptors. J Neurochem 43:1213-1219.

Blackshear MA, Steranka LR, Sanders-Bush E (1981) Multiple serotonin receptors: regional distribution and effect of raphe lesions. Eur J Pharmacol 76:325-334.

Bradford M (1976) A rapid and sensitive method for quantitation of microgram quantities of protein utilizing the principle of protein-dye binding. Anal Biochem 72:248-254.

Chaput Y, de Montigny C (1988) Effects of the 5-hydroxytryptamine1 receptor antagonist, BMY 7378, on 5-hydroxytryptamine neurotransmission: electrophysiological studies in the rat central nervous system. J Pharmacol Exp Ther 246:45-55.

Clayton C, Grosser B, Stevens W (1977) The ontogeny of corticosterone and dexamethasone receptors in rat brain. Brain Res 134:445453.

Coirini H, Magarinos AM, DeNicola AF, Rainbow TC, McEwen BS (1985) Further studies of brain aldosterone binding sites employing new mincralocorticoid and glucocorticoid markers in vitro. Brain Res 361:212-217.

Cory RN, Rouot B, Guillon G, Sladeczek F, Balestre M-N, Bockaert J (1987) The 5-hydroxytryptamine $\left(5-\mathrm{HT}_{2}\right)$ receptor stimulates inositol phosphate formation in intact and broken WRK1 cells: deter- mintiation of occupancy-response relationships for 5-HT agonists. J Pharmacol Exp Ther 241:258-267.

Fillion G, Beaudoin D, Fillion M-P, Rousselle J-C, Robaut C, Netter $Y$ (1983) 5-Hydroxytryptamine receptors in neurons and glia. J Neural Transmission, Suppl 18:307-317.

Fozard, J (1987) Neuronal 5-HT receptors in the periphery. Neuropharmacology 23:1473-1486.

Gerlach JL, McEwen BS (1972) Rat brain binds adrenal steroid hormone: radiography of hippocampus with corticosterone. Science 175 : 1133-1136.

Glennon RA, Young R (1984) Psychoactive agent with dual stimulus effects. Life Sci 34:379-383.

Hamon M (1983) Radioactive ligand binding studies: identification of central serotonin receptors. In: Methods in Neurobiology (Marangos PJ, ed). New York: Plenum.

Hertz L, Baldwin F, Schousboe A (1979) Serotonin receptors on astrocytes in primary cultures: effects of methysergide and fluoxetine. Can J Physiol Pharmacol 57:223-226.

Hoyer D, Engel G, Kalkman HO (1985) Molecular pharmacology of $5-\mathrm{HT}_{1}$ and $5-\mathrm{HT}_{2}$ recognition sites in rat and pig brain membranes: radioligand binding studies with $\left[{ }^{3} \mathrm{H}\right] 5-\mathrm{HT},\left[{ }^{3} \mathrm{H}\right] 8-\mathrm{OH}-\mathrm{DPAT}$, $(-)\left[{ }^{125} \mathrm{I}\right]$ iodocyanopindolol, $\left[{ }^{3} \mathrm{H}\right]$ mesulergine and $\left[{ }^{3} \mathrm{H}\right]$ ketanserin. Eur $\mathrm{J}$ Pharmacol 118:13-23.

Kennett GA, Curzon G (1988) Evidence that mCPP may have behavioural effects mediated by central $5-\mathrm{HT}_{\mathrm{lc}}$ receptors. Br J Pharmacol 94:137-147.

Lauder JM (1983) Hormonal and humoral influences on brain development. Psychoneuroendocrinology 8:121-155.

Levine S (1957) Infantile experience and resistence to physiological stress. Science 126:405-406.

Levine S (1962) Plasma-free corticosteroid response to electric shock in rats stimulated in infancy. Science 135:795-796.

Levine S, Haltmeyer GC, Karas GG, Denenberg VH (1967) Physiological and behavioral effects of infantile stimulation. Physiol Behav 2:55-63.

Leysen JE, Niemegeers CJE, Van Nueten JM, Laduron PM (1982) $\left[{ }^{3} \mathrm{H}\right]$ Ketanserin $(\mathrm{R} 41468)$, a selective ${ }^{3} \mathrm{H}$-ligand for serotonin 2 receptor binding sites. Mol Pharmacol 21:301-314.

Lucki I, Ward HR, Frazer A (1989) Effect of 1-(m-chlorophenyl)piperazine and 1-(m-trifluoromethylphenyl)piperazine on locomotor activity. J Pharmacol Exp Ther 249:1 55-164.

Lyon RA, Davis KH, Titeler M (1987) ${ }^{3} \mathrm{H}-\mathrm{DOB}$ (4-bromo-2,5-dimethoxyphenylisopropylamine) labels of guanyl nucleotide-sensitive state of cortical 5- $\mathrm{HT}_{2}$ receptors. Mol Pharmacol 31:194-199.

McEwen BS, Wallach G (1973) Corticosterone binding to hippocampus: nuclear and cytosol binding in vitro. Brain Res 57:373-386.

McEwen BS, Weiss JM, Schwartz LS (1969) Uptake of corticosterone by rat brain and its concentration by certain limbic structures. Brain Res 16:227-241.

McEwen BS, de Kloet ER, Rostene WH (1986) Adrenal steroid receptors and actions in the nervous system. Physiol Rev 66:11211150 .

Meaney MJ, Aitken DH (1985) The effects of early postnatal handling on the development of hippocampal glucocorticoid receptors: temporal parameters. Dev Brain Res 22:301-304.

Meaney MJ, Aitken DH, Bodnoff SR, Iny LJ, Tatarewicz JE, Sapolsky RM (1985a) Early postnatal handling alters glucocorticoid reccptor concentrations in selected brain regions. Behav Neurosci 99:760-765.

Meaney MJ, Sapolsky RM, McEwen BS (1985b) The development of the glucocorticoid receptor system in the rat limbic brain: I. Ontogeny and autoregulation. Dev Brain Res 18:159-164.

Meaney MJ, Aitken DH, Sapolsky RM (1987) Thyroid hormones influence the development of hippocampal glucocorticoid receptors in the rat: a mechanism for the effects of postnatal handling on the development of the adrenocortical stress response. Neuroendocrinology 45:278-283.

Meaney MJ, Aitken DH, Bhatnagar S, Van Berkel C, Sapolsky RM (1988) Postnatal handling attenuates neuroendocrine, anatomical, and cognitive impairments related to the aged hippocampus. Science 238:766-768.

Mcancy MJ, Aitken DH, Sharma S, Viau V, Sarricau A (1989) Postnatal handling increases hippocampal type II, glucocorticoid receptors and enhances adrenocortical negative-feedback efficacy in the rat. Neuroendocrinology 50:597-604.

Mitchell JB, Iny LJ, Meaney MJ (1990) The role of serotonin in the 
development and environmental regulation of hippocampal type II corticosteroid receptor binding. Dev Brain Res (in press).

Olpe HR, McEwen BS (1976) Glucocorticoid binding to receptor-like proteins in rat brain and pituitary: ontogenetic and experimentallyinduced changes. Brain Res 105:121-128.

Peroutka SJ (1985) Selective labelling of 5- $\mathrm{HT}_{\mathrm{la}}$ and $5-\mathrm{HT}_{\mathrm{lb}}$ binding sites in bovine brain. Brain Res 344:167-171.

Peroutka SJ (1988) 5-Hydroxytryptamine receptor subtypes: molecular, biochemical and physiological characterization. Trends Neurosci 11:496-500.

Peroutka SJ, Hamik A (1988) [ $\left.{ }^{3} \mathrm{H}\right]$ Quipazine labels 5-HT 3 recognition sites in rat cortical membranes. Eur J Pharmacol 148:297-299.

Philbert D, Moguilewsky M (1983) RU 28362, a useful tool for the characterization of glucocorticoid and mineralocorticoid receptors. Endocrine Soc Abstr 335.

Reul JMHM, de Kloet ER (1985) Two receptor systems for corticosterone in rat brain: microdistribution and differential occupation. Endocrinology 117:2505-2511.

Richardson BP, Engel G, Donatsch P, Stadler PA (1985) Identification of serotonin type M-receptor subtypes and their specific blockade by a new class of drugs. Nature 316:126.

Rosenfield P, Sutanto W, Levine S, de Kloet ER (1988) Ontogeny of type I and type II corticosteroid receptors in the rat hippocampus. Dev Brain Res 42:113-118.

Sanders-Bush E, Burris KD, Knoth K (1988) Lysergic acid diethylamine and 2,5-dimethoxy-4-methylamphetamine are partial agonists at serotonin receptors linked to phosphoinositide hydrolysis. J Pharmacol Exp Ther 246:924-928.

Sapolsky RM, Meaney MJ (1986) The maturation of the adrenocortical stress response in the rat. Brain Res Rev 11:65-76.

Sapolsky RM, Krey LC, McEwen BS (1984) Stress down-regulates corticosterone receptors in a site-specific manner. Endocrinology 114: 287-292.
Sarrieau A, Sharma S, Meaney MJ (1988) Postnatal development and environmental regulation of hippocampal glucocorticoid and mineralocorticoid receptors in the rat. Dev Brain Res 43:158-162.

Scatchard G (1949) The attraction of proteins for small molecules and ions. Ann NY Acad Sci 51:660-672.

Shannon M, Battaglia G, Glennon RA, Titeler M (1984) 5-HT, and $5-\mathrm{HT}_{2}$ binding properties of derivatives of the hallucinogen $1-(2,5-$ dimethoxyphenyl)-2-aminopropane(2,5-DMA). Eur J Pharmacol 102: 23-29.

Sheppard KE, Funder JW (1987) Equivalent affinity of aldosterone and corticosterone for type I receptors in kidney and hippocampus: direct binding studies. J Steroid Biochem 28:737-742.

Titeler M, Battaglia G, Shannon M (1984) Guanine nucleotides modulate cortical S2 serotonin receptors. J Receptor Res 7:705-712.

Titeler M, Lyon RA, Davis KH, Glennon RA (1987) Selectivity of serotonergic drugs for multiple brain serotonin receptors. Biochem Pharmacol 36:3265-3271.

Tornello S, Orti E, DeNicola AF, Rainbow TC, McEwen BS (1982) Regulation of glucocorticoid receptors in brain by corticosterone treatment of adrenalectomized rats. Neuroendocrinology 35:411-417.

Turner BB (1986) Tissue differences in the up-regulation of glucocorticoid binding proteins in the rat. Endocrinology 118:1211-1216.

Veldhuis HD, van Koppen C, van Ittersum M, de Kloet ER (1982) Specificity of adrenal steroid receptor system in rat hippocampus. Endocrinology 110:2044-2051.

Whitaker-Azmitia PM, Lauder JM Shemmer A, Azmitia EC (1987) Postnatal changes in serotonin receptors following prenatal alterations in serotonin levels: further evidence for functional fetal serotonin receptors. Dev Brain Res 42:285-289.

Yocca FD, Hyslop DK, Smith DW, Maayani S (1987) BMY 7378, a buspirone analog with high affinity, selectivity, and low intrinsic activity at the 5-HT1a receptor in rat and guinea pig hippocampal membranes. Eur J Pharmacol 137:293-294. 